\title{
Just in time and competitive advantage: understanding their linkages and impact on operational performance
}

\author{
Ramlawati \\ Lecturer in Management Science, \\ University of Muslim Indonesia, Indonesia
}

\begin{abstract}
This study aims to analyze the influence of Just in Time on competitive advantage and operational performance. This research was carried out on a manufacturing company in Makassar Industrial Area, a sample of 40 respondents consisting of marketing managers, production managers and financial managers. The results of data analysis using Partial Least Square (PLS) provide evidence that Just in Time has a significant effect on competitive advantage and operational performance
\end{abstract}

Keywords: Just in time, competitive advantage, operational performance

\section{INTRODUCTION}

Makassar Industrial Region (KIMA) is an Industrial Region located north of Makassar City which has a very strategic location because it has very easy access to the Port and to the Airport. Access to Makassar Industrial Region can be via toll roads. Sometime in the future this industrial area will be connected to the trans-Sulawesi railroad roads. Thus, the process of transporting raw materials becomes easier and cheaper. Makassar Industrial Region is also equipped with various supporting facilities, namely water-treatment, third-party services such as electrical energy sources from PT Perusahaan Listrik Negara (PLN) (Persero) and clean water from Regional Water Supply Companies (PDAM) Makassar City and networks telecommunications from PT Telkom Indonesia (Persero). The availability of these supporting facilities is expected to stimulate the interest of entrepreneurs or investors to place their business in the Makassar Industrial Region. In addition, Makassar City is located in the middle of Indonesia, whose territory stretches from Sabang to Merauke, and in the Makassar Strait which is the shipping axis from Australia to the East Asia and Pacific Ocean regions.

The position of Makassar Industrial Region which strategically gives economic value to companies located in Makassar Industrial Region. Transportation facilities and other supporting facilities contribute to the company's business, especially manufacturing companies in the implementation of the Just in Time Production System. On the other hand there has been an awareness of entrepreneurs to adopt the ISO 9001: 2008 Quality Management System and SNI-19-9001: 2008. Through the implementation of a Quality Management System consistently, the quality of output can be improved.

This is a support for companies to have a competitive advantage. In turn, companies can improve their operational performance. Various philosophies and approaches to developing manufacturing and service businesses have been introduced by a number of experts. The Toyota Production System (TPS) in its implementation has several approaches, including Just in Time (JIT) and Total Quality Control (TQC) which is then refined to Total Quality Management (TQM), in addition there are several other approaches, namely Total Preventive Management (TPM), Kaizen and Poka Yoke. All of these approaches in their application in various manufacturing and service companies turned out to yield good results. Empirical evidence shows that just in time (JIT), Supply Chain Management (SCM) and Total Quality 
Management (TQM) at the strategic and operational levels contribute positively to the company's performance, commitment to the quality and dynamics of Supply Chain Management is a very factor in improving company performance (Kannan \& Tan, 2005).

Application of just in Time and inventory systems provide a strong influence on the efficiency, quality of output and flexibility of small and medium scale manufacturing companies in South Africa (Mazanai, 2012). An interesting result is shown that JIT-purchasing has a direct positive relationship with agile manufacturing. Improved operational performance resulted in an increase in firm performance as a consequence to agile manufacturing is mediated by JITpurchasing. Agile manufacturing has a direct positive relationship with the company's operational performance and the company's operational performance has a direct positive relationship with the company's marketing performance. In addition, it is also proven that there is a positive relationship between operational performance and the company's financial performance is mediated by marketing performance (Inman et al., 2011). The findings relevant to some of these studies also show similar evidence that compatibility of the JIT, TQM and TPM practices are associated with the implementation of both socially and technically-oriented practices of the three programs (Cua et al., 2001). Some of the findings from previous researchers are the reason for this research, which is whether there is a direct influence of JIT on operational performance and how the role of competitive advantage is as a variable mediated. This is important to do because the intense competition at this time encourages manufacturing companies to be the best so that the company can preserve its existence. Competitive advantage is expected to be obtained through the implementation of JIT. The application of JIT directly or indirectly through competitive advantage is expected to improve the company's operational performance. Operations managers in manufacturing companies are expected to find the right method so that the company has a competitive advantage. This expectation is in line with the views of scholars (Heizer \& Render, 2005; Mulia, 2009), that the success of forming a unique and high-superior system compared to competitors can improve the company's capability in operations and marketing so that it can serve all its customers efficiently, consistent and sustainable.

\section{Operational performance}

\section{LITERATURE REVIEW}

Operational performance as the ability of product makers to find standards of expectations built for customers (Tracey \& Vonderembse, 2000). Other scholars say that operational performance is an achievement to measure whether the product produced is in accordance with the product planned (Christiansen et al., 2003). Operational performance refers to measurable aspects of the results of an organization's processes, such as reliability, cycle of production time and inventory turnover. Operational performance in turn affects business performance measures such as market control and customer satisfaction (Voss et al., 1997).

The company's operational performance can be assessed or viewed from two dimensions, namely: dimensions of cost, flexibility and quality of delivery (Brah \& Lim, 2006). The cost dimension is measured by five indicators, and the dimensions of flexibility and quality of delivery are measured by three indicators (Carton, 2004; Carton \& Hofer, 2006; Venkatraman \& Ramanujam, 1986). This operational performance can be measured using measurements such as market share, new product launches, quality, marketing effectiveness, and customer satisfaction. Other scholars identify operational performance from the waste level, productivity, cycle time aspects (Lakhal et al., 2006). Operational performance refers to the measurable aspects of the results of an organization's processes, such as reliability, cycle of 
production time and inventory turnover. Operational performance in turn affects business performance measures such as market control and customer satisfaction (Voss et al., 1997).

\section{Competitive advantage}

The competitive advantage is an advantage against competitors gained by offering a lower value or to provide a greater benefit because the price is higher (Kotler \& Armstrong, 2003). An important factor in creating competitive advantage is an efficiency, innovation, quality, and customer response. Companies that are able to adopt the four basic components of Competitive Advantage will succeed in cost leadership and differentiation, and ultimately gain competitive advantage. These four factors can be explained as: (1) Efficiency, (2) Quality) Innovation, Customer response (Chin \& Heng, 2009). There are five dimensions of priority for competitive advantage, namely: (1) Price; (2) Quality; (3) Dependability; (4) Product Flexibility; (5) Volume Flexibility (Hayes \& Schmenner, 1978). Competitive advantage of a company can be measured using indicators; price, quality, delivery dependability, product innovation, and time to market (Li et al., 2006).

\section{Just In Time.}

Just-in-Time is known as a philosophy for completing products at every instant (Just-in-time) and with a minimum cost that aims to eliminate waste through continuous improvement on all key aspects of the production process including several factors that influence the application of the model and inventory method (Kannan \& Tan, 2005). Just-in-time contributes to the company through; (1) reduce the amount of inventory in the process, goods purchased and finished goods; (2) reduce floor area requirements; (3) improve the quality and reduce the wasted goods and which must be reworked, (4) reduce the production time cycle; (5) provide high flexibility to produce various types of goods; (6) smoother production flows, fewer production disruptions caused by quality problems, shorter tide times, jobs with several skills that can help each other and replace other workers when they are unable to attend; (7) increase productivity and use of machinery and equipment; and (8) participation of workers in solving problems (Stevenson, 2002).

Just in Time are defined as a time base marketing pull strategy combined with total process minimization. The purpose of this strategy is the delivery of products and services that are zero defects in the right number at the right time and right as desired by consumers while minimizing the type of waste. Implementation of this strategy reconciles fundamental changes in the way the sales function is implemented, which requires sellers to produce strong alliances with consumers (Germain et al., 1994). The JIT production strategy is applied to all modern industrial systems from engineering (engineering), material ordering from suppliers, material management in industry, manufacturing processes, to distribution of industrial products to customers. "It appears that modern industrial systems are oriented to customer satisfaction by way of integrating the three main components, namely: material supplier (input), manufacturing process (factory process) and customers (customers) as a complete system (Gaspersz, 2005).

The instrument used to measure just-in-time in this study uses: (1) limited number of suppliers, (2) minimum inventory in the factory, (3) factory layout, (4) reduction in set up time, (5) integrated control and (6) flexible labor (Simamora, 2002). JIT-purchasing is understood as a delivery control system and makes quantitative models to compare it with traditional procedures (Chyr et al., 1990; Fazel, 1997; Fazel et al., 1998). Other researchers use broader perspectives and focus on identifying practices that describe JIT-purchasing which aims to transfer the JIT production system into the supply chain (Schonberger \& Gilberg 1983; Lee \& Ansari, 1985; Fawcett \& Birou, 1993; Waters, 1995; Ansari \& Modarres, 1988; De Toni \& 
Nassimbeni, 2000). Therefore, this practice affects not only logistics but also other aspects related to supply relations, such as procedures, selection, design specifications or length of contract (González-Benito \& Spring, 2000).

Some other researchers consider .Just In Time Purchases as a result of several cooperative principles and advantages of risk sharing between buyers and suppliers (O'Neal, 1987; Leavy, 1994). JIT total system contains three dimensions, namely Just in Time purchase, Just in Time production and Just in Time sales. As expected it was found that Just in Time the total system was positively related to financial results. Correlation matrix shows the same results when Just In Time sales are considered separately Although they do not provide a specific definition of Just In Time sales, they continue to operate (Claycomb et al., 1999). Other researchers' findings provide evidence that the percentage of open-ended single sales made according to JIT questions. They identify this single measurement as a limitation of study and require future research to produce a valid and feasible measurement scale (Germain et al., 1994).

\section{RESEARCH FRAMEWORK}

Conceptually the statement of the relationship between research variables is built based on relevant theories and the results of previous research. Theoretical and empirical findings are used as a basis for describing the conceptual framework of research and are used as a basis for deriving the research hypothesis. Competitive Advantage Theory explains that there are four main attributes that make up the environment in which the company competes in such a way, which encourages the creation of competitive advantage (Michael E. Porter, 1990), these four attributes are: (1) production factor conditions, namely the position of a country in a factor production (e.g. skilled labor, infrastructure, and technology) needed to compete in certain industries, (2) demand conditions, namely the nature of domestic demand for certain industrial products or services, (3) related and supporting industries, namely the presence or absence of industry suppliers and related industries that are internationally competitive in the country, and (4) Strategy, structure and competition of companies, namely domestic conditions that determine how companies are formed, organized and managed and the nature of domestic competition. Other scholars explain competitive advantage as everything that is intended to create competitive advantage.

The company is advised to form a unique system and has distinctive advantages compared to its competitors. This is done by submitting the best according to what is expected by consumers efficiently and continuously (Meylianti \& Mulia, 2006; Heizer \& Render, 2005). There are five objective bases for operational performance that are considered to be applied to all types of operations. Operational performance indicators that can be implemented include quality, speed of delivery, networking, flexibility and cost. This indicator provides support for competition. The application needs to be supported by operating management tools and techniques, such as Kanban System, Statistical Process Control (SPC) and JIT (Slack et al., 2004). All of this equipment focuses on activities that do things better, faster, more efficiently and cheaper (Staughton \& Johnston, 2005).

Just in Time is a philosophical concept to produce products that are needed when the customer needs the appropriate amount of needs, as well as a primary quality level. At every stage of the process in system manufacturing carried out in the most economical and efficient way through elimination of waste and process improvement continuously (Gaspersz, 2008) Empirical evidence shows that so is just-in-time (JIT), that in order to face competition, every company is required to always increase competitive advantage, both in the domestic market and in the global market. To increase competitive advantage, many companies apply various 
management models, one of which is just-in-time (Ramarapu et al., 1995). Relevant to these results, the findings of other researchers indicate that there is a positive and statistically significant relationship. Implementing a JIT system, competitive advantage can be achieved for the manufacturing company concerned, namely achieving three dimensions of competitive advantage (low production costs, excellent product quality and financial performance the good (Alshbiel \& Al-Awaqleh, 2012).

Wider results show that a structural model combines agile manufacturing as a theoretical construct and will be tested. This model includes the main components of JIT (purchasing and JIT-production) as antecedents and operational performance and company performance as a consequence of agile manufacturing Using data collected from production and operations managers working for producers in the United States The model used follows the structural equation methodology. The results show that JIT-purchasing has a direct positive relationship with agile manufacturing while a positive relationship between agile manufacturing is mediated by JIT-purchasing. The results also show that agile manufacturing has a direct positive relationship with the company's operational performance, that the company's operational performance has a direct positive relationship with the company's marketing performance and that a positive relationship between the company's operational performance and the company's financial performance is mediated by the company's marketing performance (Inman et al., 2011). These facts and statements form the basis for the use of hypotheses in this study, so that they are described as follows:

$\mathrm{H}_{1}$ : Just in time are more likely to be associated with significant improvements in competitive advantage.

$\mathrm{H}_{2}$ : Competitive advantage are more likely to be associated with significant improvements in operational performance

$\mathrm{H}_{3}$ : Just in time are more likely to be associated with significant improvements in operational performance

$\mathrm{H}_{4}$ : The positive association between just in time and operational performance is mediated through competitive advantage

\section{METHODS}

The research is survey type and data were collected using questionnaire, and 40 people (i.e. marketing managers, production managers and financial managers) were selected as sample using simple random sampling. In order to answer the research hypotheses, confirmatory factor analysis (CFA) and structural equation modeling (SEM) using SmartPLS software were utilized

\section{Outer model (measurement model)}

\section{RESULTS}

The outer model or measurement model is the assessment of the validity and reliability. There are three criteria for assessing the outer model, namely: convergent validity, convergent validity test is used to test whether the indicators used are able to measure latent constructs accurately (Hair et al., 2014). The latent variable indicator is represented by the dimension score that has previously been tested for its validity and reliability. From testing convergent validity with SmartPLS can be seen the value of loading factor for each indicator. Loading factor values are identical to simple correlations between indicator scores and latent variable scores. The cut-off value required is at least 0.7 or t-statistics $>1.96$ (Ghozali, 2011). The result of convergent validity indicators of the study are presented in Table 1. 
Table 1. Loading factor and composite reability

\begin{tabular}{lcccc}
\hline \multicolumn{1}{c}{ Variable } & Construct / Items & Loading Factor & t-statistics & $\begin{array}{c}\text { Composite } \\
\text { Reability }\end{array}$ \\
\hline \multirow{3}{*}{ Operational } & $\mathrm{KOP}_{1}$ & 0.907 & 29.969 & \\
performance (KOP) & $\mathrm{KOP}_{2}$ & 0.904 & 37.280 & \\
& $\mathrm{KOP}_{3}$ & 0.886 & 21.049 & 0.963 \\
& $\mathrm{KOP}_{4}$ & 0.927 & 28.599 & \\
$\mathrm{KOP}_{5}$ & 0,959 & 122.282 & \\
Competitive & $\mathrm{KPT}_{1}$ & 0.965 & 69.224 & \\
advantage (OPT) & $\mathrm{KPT}_{2}$ & 0.849 & 12.639 & \\
& $\mathrm{KPT}_{3}$ & 0.956 & 106.321 & \\
& $\mathrm{KPT}_{4}$ & 0.846 & 12.033 & \\
$\mathrm{KPT}_{5}$ & 0.731 & 8.972 & \\
& $\mathrm{JIT}_{1}$ & 0.772 & 13.568 & \\
Just-in-Time & $\mathrm{JIT}_{2}$ & 0.817 & 14.419 & \\
(JIT) & $\mathrm{JIT}_{3}$ & 0.784 & 10.883 & \\
& $\mathrm{JIT}_{4}$ & 0.764 & 11.874 & \\
& $\mathrm{JIT}_{5}$ & 0.861 & 33.559 & \\
\hline
\end{tabular}

The value of Just in Time has a value $>0.70$ so that all the indicators that make up the variable in question fulfill convergent validity. For the operational performance variable, the biggest contribution is by $\mathrm{Y}_{25}$ (ability of the company to meet customer needs), and the lowest contribution of its formation is $\mathrm{Y}_{23}$ (adjustment of products with baking needs), on the variable the Competitive Advantage biggest contribution of its formation is $\mathrm{Y}_{11}$ (price advantage) and contribution the lowest formation is given by $\mathrm{Y}_{15}$ (Time to Market), and the Just In Time variable has the largest contribution, $\mathrm{X}_{15}$ (integrated quality control) and the lowest contribution is the formation of $\mathrm{X}_{11}$ (number of suppliers). And it can be seen that the variable t-statistic is just in time, competitive advantage, and operational performance in this study is greater than 2,024. This shows that the indicators are valid.

\section{Discriminant validity}

Test Subsequent testing in the partial least square analysis is discriminant validity. An indicator is said to meet discriminant validity if the value of cross loading indicator on the construct is the biggest compared to other constructs. Following are the results of the cross loading output. Discriminant Validity is used to test whether the indicators of a construct are not highly correlated with other construct indicators or at least these indicators are lower correlated with other construct indicators (Hair et al., 2014). Testing discriminant validity by comparing loading with cross-loading 
Table 2. Discriminant validity test (cross loadings)

\begin{tabular}{ccccc}
\hline Variable & Indicator & KOP & KPT & JIT \\
\hline & $\mathrm{KOP}_{1}$ & $\mathbf{0 . 9 0 7}$ & 0.542 & 0.506 \\
Operational & $\mathrm{KOP}_{2}$ & $\mathbf{0 . 9 0 4}$ & 0.454 & 0.439 \\
performance & $\mathrm{KOP}_{3}$ & $\mathbf{0 . 8 8 6}$ & 0.491 & 0.409 \\
(KOP) & $\mathrm{KOP}_{4}$ & $\mathbf{0 . 9 2 7}$ & 0.509 & 0.493 \\
& $\mathrm{KOP}_{5}$ & $\mathbf{0 . 9 5 9}$ & 0.631 & 0.625 \\
& $\mathrm{KPT}_{1}$ & 0.548 & $\mathbf{0 . 9 5 6}$ & 0.706 \\
Competitive & $\mathrm{KPT}_{2}$ & 0.504 & $\mathbf{0 . 8 4 9}$ & 0.643 \\
advantage & $\mathrm{KPT}_{3}$ & 0.565 & $\mathbf{0 . 9 6 5}$ & 0.739 \\
(KPT) & $\mathrm{KPT}_{4}$ & 0.524 & $\mathbf{0 . 8 4 5}$ & 0.656 \\
& $\mathrm{KPT}_{5}$ & 0.365 & $\mathbf{0 . 7 3 1}$ & 0.519 \\
& $\mathrm{JIT}_{1}$ & 0.387 & 0.617 & $\mathbf{0 . 7 7 2}$ \\
Just-in-Time & $\mathrm{JIT}_{2}$ & 0.368 & 0.530 & $\mathbf{0 . 8 1 7}$ \\
(JIT) & $\mathrm{JIT}_{4}$ & 0.425 & 0.600 & $\mathbf{0 . 7 8 4}$ \\
& $\mathrm{JIT}_{5}$ & 0.469 & 0.522 & $\mathbf{0 . 7 6 4}$ \\
& $\mathrm{JIT}_{6}$ & 0.511 & 0.687 & $\mathbf{0 . 8 6 1}$ \\
& & 0.471 & 0.658 & $\mathbf{0 . 8 3 3}$ \\
\hline
\end{tabular}

Table 2. Shows that each indicator has a value which is the biggest factor loading on variables that shape when compared with the value of the other variables. Therefore it can be concluded that all empirical indicators used have met discriminant validity criteria when viewed from the results of cross loading.

\section{Reliability analysis}

Reliability reflects the consistency of the results of repeated measurements on the same subject. If the results are consistent, then the measuring instrument is considered reliable or reliable. The reliability test as a set of latent variables consistent with measurement, that the high level of reliability means being able to provide reliable measurement results. The criteria for determining the level of reliability according to the level of reliability of a construct reliability in a Structural Equation Model (SEM) are calculated by looking at the composite reliability value, where if the composite reliability value is greater than 0.7 it can be declared reliable (Ghozali, 2011; Sjahruddin, \& Sudiro, 2013; Hair et al., 2014). In summary, the latency composite reliability value can be described as follows: operational performance $=0.963$, just in time $=0.917$ and competitive advantage $=0.941$. This means that the indicators support each other to be used as a measure of latent variables (see in table 1).

\section{Inner model (structural model)}

Testing the inner model (original sample estimated) is used to test the hypothesis proposed in this study because the hypothesis formulated is reflected in the paths in the model. The results of testing the inner model can be seen in Figure 


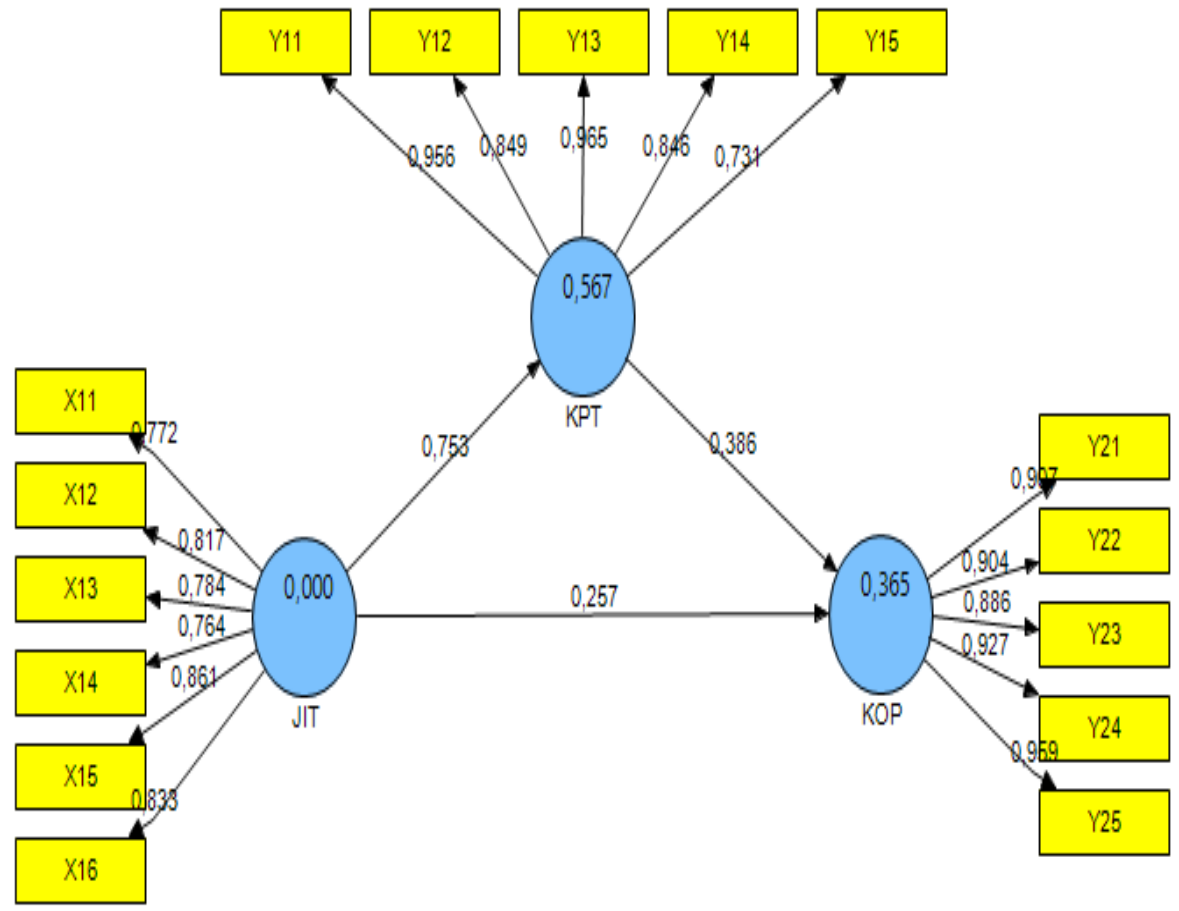

Figure 1. Inner model

\section{Goodness of fit test}

This test is intended to determine how much the results of the model are able to explain the variation of the original variable (score) variables. The test was carried out with Stone-Geisser Q Square test. From the inner model it is known that there are two endogenous variables namely Competitive Advantage and Operational Performance so that two determinant coefficients are obtained. The determinant coefficient value for each endogenous variable is as in the following table:

Table 3. R-square

\begin{tabular}{|c|c|c|c|}
\hline Equations & Exogenous Variable & Endogenous variables & R-square \\
\hline \multirow{2}{*}{1.} & \multirow{2}{*}{ JIT } & KPT & 0.566947 \\
\hline & & KOP & 0.364784 \\
\hline
\end{tabular}

Next based on the coefficient of determination of each dependent variable $\mathrm{Q}^{2}$ with the formula:

$$
\mathrm{Q}^{2}=1-\left(1-\mathrm{R}_{1}^{2}\right)\left(1-\mathrm{R}_{2}^{2}\right)
$$

Description:

$\mathrm{R}_{1}^{2}=$ Coefficient of determination (KPT)

$\mathrm{R}_{2}{ }^{2}=$ Coefficient of Determination (KOP)

$\mathrm{Q}^{2}=[1-(1-0.566947)(1-0.364784)]$

$\mathrm{Q}^{2}=[0,724484753]=0.72,45 \%$

Based on the coefficient of determination of the two endogenous variables in the model, it can be seen that Stone-Geisser Q Square is 0.72448 or $72.45 \%$. These results indicate that the model has good feasibility because it is able to explain the information contained in the original data of $77.2 \%$ while the rest is $27.55 \%$, explained by other variables and error variables. The value of the determination coefficient is high, so the model is worth interpreting. 


\section{Hypothesis testing}

Research proposes 4 (four) hypotheses, testing hypotheses in the SmartPLS analysis, basically testing the significance of the path coefficients in the model, to conclude whether the research pathway or hypothesis is proven, if the path coefficient value is $\geq 2.024$.

Table 4. Hypothesis Testing of Direct and Indirect

\begin{tabular}{ccccccc}
\hline EXV & MV & ENV & $\underline{\text { DE }}$ & $\underline{\text { IE }}$ & TE & $\underline{\text { P-value }>2.024}$ \\
\hline JIT & $\rightarrow$ & KPT & $\underline{0.753}$ & - & $\underline{0.753}$ & 18,148 \\
JIT & $\rightarrow$ & KPT & $\underline{0.257}$ & - & $\underline{0.257}$ & 2,055 \\
KPT & $\rightarrow$ & KOP & $\underline{0.386}$ & - & $\underline{0.386}$ & 4,139 \\
JIT & $\rightarrow$ KPT $\rightarrow$ & KOP & $\underline{0.753}$ & $\underline{0,153}$ & $\underline{0,906}$ & $\underline{4,090}$ \\
\hline
\end{tabular}

Notes:

$\begin{array}{llll}\text { EXV } & \text { Exogenous variable } & \text { DE } & : \text { Direct effect } \\ \text { MV } & : \text { Mediating variable } & \text { IE } & : \text { Indirect effect } \\ \text { ENV } & : \text { Endogenous variable } & \text { TE } & : \text { Total effect }\end{array}$

\section{Just in time to be associated in competitive advantage}

In face of competition globally, every company is required to always increase competitive advantage, both in the domestic market and in the global market. To increase competitive advantage, many companies apply various management models (i.e. Just in Time) (Ramarapu et al., 1995). The results of the descriptive analysis of the variable value (mean) the average score in just in time variables was obtained through an integrated quality control indicator which has the highest value of 4.26 , among the five other indicators of just in time variables while the lowest is the level indicator minimal. Based on empirical facts, integrated quality control indicators are shown by not receiving defective components or raw materials from suppliers, suppliers are responsible for components and raw materials before the production process is carried out, and production part employees are responsible for supervision of the products already good if used as a measurement or an indicator of just in time variables so it must be maintained. Just in time, is competitive in competitive advantage. Based on the results of the analysis, the t-statistic value is 18,148 . Then for the $t$-table at the $0.05 \%$ error level is = 2.024. Based on these results it can be stated that the value of t-statistics $>t$-table or 18.148> 2.024 .

This means applying Just in Time positive and significant influence on competitive advantage. Coefficient value with a positive sign explains that if JIT application is improved, the competitive advantage of manufacturing companies will also increase, so the first hypothesis proposed in this study is proven to be accepted or supported by empirical facts. Results Outer Loadings show the same fact that important or dominant factors reflecting just in time variables are statistical control indicators of 0.892 or $89.2 \%$ of their roles in reflecting just in time. The results of this study confirm that good in-time is reflected through a variable indicator of statistical quality control. Whereas variable indicators have the smallest contribution in reflecting just in time latent variables, which are minimal inventory levels, it needs serious attention from the management of manufacturing companies in Makassar Industrial Area. The just in time effect on competitive advantage can be proven by the path coefficients value of 0.265 with a positive direction. The positive influence coefficient means that good just in time tends to increase the company's competitive advantage. Besides that, it can also be proved by the value of T Statistics $(\mid \mathrm{O} / \mathrm{STER})=2.708956>1.96$ (t-critical) .

The test results prove that just in time has a positive and significant effect on the competitive 
advantage of manufacturing companies in Makassar Industrial Area. Based on these conditions it can be concluded that just in time changes are positive and real towards increasing the company's competitive advantage so that it can be supported by empirical facts. The indicator that contributes the most to the formation of Just in time variables is an indicator of integrated quality control and skilled labor. This reveals that to increase the support capacity of just in time to competitive advantage and operational performance, companies must produce quality products, through the most efficient and economical way, and on time, that is when the product is needed by consumers. Quality control involves developing a system to ensure that the product is designed and manufactured to meet the requirements of the customers and producers themselves. The results of this study support conceptual stating that Just in time is a comprehensive production system (all parts) and inventory management system where materials and spare parts are purchased and produced as much as needed and at the right time at each stage of production. This is inseparable from the skilled workforce that the company has expertise in operating all production equipment or machines contained in the work line, and equipped with skills, maintenance of production equipment used to be able to carry out maintenance and repair it if it experiences interference (Chen et al., 2006).

The results of this study are in line with statements from several experts that the successful implementation of JIT in a company can improve the quality of products and services produced, reduce operational costs, and increase customer satisfaction (Sakakibara et al., 1997; Golhar \& Stamm, 1991). The results of this study are in line with the findings of previous researchers that the application of just in time has a significant effect on competitive advantage (Alshbiel, \& Al-Awaqleh, 2012). Just-in-time implementation can provide great benefits to companies in the form of reducing inventory costs, increasing productivity, and better product quality, thus ultimately increasing the company's competitive advantage (Golhar \& Stamm, 1991).

\section{Just in time to be associated in operational performance}

Just-in-time is the manager's response to the inventory and production control system that is carried out continuously to suppress corporate waste. The results of the descriptive analysis show the empirical condition that the application of the six indicator variables Just-in time, namely the limited number of suppliers, inventory level of control, appropriate delivery of orders, statistical quality control, and employee flexibility are seen as important in explaining just in time variables. Variable indicators that have the highest average (mean) score indicated by the indicator of the number of suppliers with an average score (mean) of 4.30, this condition can be explained that the supplier is responsible for supplying raw materials that are not defective and part employee's production responsibility for production. Just in time are more likely to be associated with significant improvements in operational performance.

Hypothesis testing provides evidence that the value of $t$-statistic is $=3,853$. Then for the $t$-table value at the $0.05 \%$ error level is $=2.024$. Thus the value of t-statistics $>t$-table, or 3,853>2,024 is obtained. This means that the application of competitive advantage has a positive and significant effect on operational performance. A positive path coefficient value explains that if the company's competitive advantage is increased, the increase will have an impact on improving the operational performance of the manufacturing company. So that the third hypothesis proposed in this study is proven to be accepted or supported by empirical facts. Outer Loadings results indicate that important or dominant factors reflecting just in time variables are the same indicators as the results of descriptive statistics, namely on the quality control variable indicator with the Outer Loadings value of 0.899 , meaning that to produce a quality product with the use of a raw material inventory control system function to minimize 
the occurrence of waste can be achieved by increasing the responsibility of suppliers to the supply of raw materials and employee responsibility for the creation of quality products that have a contribution or role of $89.90 \%$ in reflecting the just in time variable, but it can also be explained that the lowest contribution is based on factor analysis confirmatory is shown through minimal inventory levels.

Based on the indicators of the indicator managers who need to get serious attention in the management of just in time is a good indicator that is the minimum inventory level so it is very important to be improved. The results of testing the effect of just in time on operational performance can be proven by the Path Coefficients of 0.241 with a positive direction. The positive influence coefficient means that good just in time tends to improve operational performance. Then it can be proved T Statistics (| O / STERR 1.003955 (t-critical)> 0.196. The findings of this study prove that just in time has a positive and significant effect on improving operational performance. The results of testing just in time effect on operational performance based on the value of the Path Coefficients amounting to 0.241 with a positive direction, this is because managers generally agree that there are even some managers who strongly agree if the company purchases parts and raw materials only when the product is ordered and the amount of raw material to be produced is in accordance with the number of orders and the company does not store spare goods in the warehouse as a reflection of the indicator of the minimum inventory level variable. That condition can be concluded that the inventory and production control system carried out continuously has been carried out properly so that the company does not incur unnecessary costs yes (there is no waste of costs).

The poorly resulting consequences of a implemented inventory and production control system and the occurrence of cost waste, have an impact on the company's low ability to reduce production costs (indicators of financial performance variables) and the inability of companies to meet customer / market needs (indicator of operational performance variables). In general, it can be stated that just in time has not been implemented properly, which has an impact on the occurrence of a decrease in the performance of manufacturing companies in the Makassar Industrial Area. This research is in line with the findings of previous researchers that the application of JIT in a company can improve the quality of products and services produced, reduce operational costs, and increase customer satisfaction that affect the company's financial performance (Flynn et al., 1995). This study is relevant to findings that provide evidence that JIT production positively influences efficiency and delivery (Danese et al., 2012).

\section{Competitive advantage to be associated in operational performance.}

The creation of a high competitive advantage can be done by creating a special competitive advantage so that companies have a strong bargaining position (bargaining power) in business competition (Porter, 1990). Competitive advantage is more likely to be associated with significant improvements in operational performance. Based on the results of the analysis, the value of $t$-statistic was 2.055. Then for the $t$-table value at the $0.05 \%$ error level is $=2.024$. Thus the value of t-statistics is obtained $>t$-table or 2.055>2.024. This means applying Just in Time positive and significant effect on operational performance. Path coefficient value positive sign explains that when applying Just in Time improved, the increase in operational performance will also increase, so that the second hypothesis proposed in this study is proven to be accepted or supported by empirical facts.

Analysis of outer loadings show that important or dominant factors that reflect competitive advantage variables are indicators of price excellence in reflecting competitive advantage. The results of this study confirm that a high competitive advantage is reflected through variable indicators of price excellence. While variable indicators that have the smallest role or 
contribution in reflecting the latent variable of competitive advantage is the time to market variable indicator, so it needs serious attention from the management of manufacturing companies in Makassar Industrial Area.

The effect of competitive advantage on operational performance can be proved by the path coefficients value with a positive direction. Positive influence coefficient means that high competitive advantage tends to improve operational performance. Besides that, it can also be proven that the $\mathrm{T}$ Statistics value is greater than the critical value. The test results prove that competitive advantage has a positive and significant effect on the performance of manufacturing operations in the Makassar Industrial Area. Based on these conditions it can be concluded that changes in competitive advantage are positive and real towards improving operational performance so that they can be supported by empirical facts. This finding is relevant to the findings of previous scholars that there is a significant relationship between competitive advantage against supply chain performance only accepted at high operational performance but rejected at low operational performance (Chi et al., 2009). In contrast to the results of other studies that competitive advantage does not have a significant effect on the operational performance of small companies, but on large scale companies have a significant effect (Wook, 2006).

\section{Just in time and operational performance is mediated through competitive advantage.}

Based on The Sobel's test is to determine the indirect coefficient of influence shown in Table 3. That just in time indirectly has a significant effect on improving operational performance, as well as competitive advantage on operational performance. So it can be concluded that good just in time and high competitive advantage indirectly have a significant effect on increasing operational performance in a high direction. The positive association between just in time and operational performance is mediated through competitive advantage. The test results using Sobel test prove that the value of t-statistics $>t$-table or 3.820 $>2.024$. These results explain that the application of just in time (JIT) has a positive and significant impact on operational performance through competitive advantage. The positive-marked path coefficient explains that competitive advantage is able to act as a mediator variable in analyzing the influence of just in time on the operational performance of manufacturing companies. So that the fourth hypothesis proposed in this study is proven to be accepted or supported by empirical facts.

This statement can be proven through the Sobel test's results of testing the indirect effect of just in time variables on operational performance through mediation of competitive advantage obtained by the path coefficient value of 0.153 . That just this time path coefficient value to competitive advantage is 0.753, and the T Statistics (| O / STERR |) value is 4.090, 2.024 greater so that it can be said to be significant. So it can be concluded that just in time which is getting better indirectly has a significant effect on operational performance. This means that just this time indirectly influences the operational performance after being mediated by competitive advantage; the supply chain management has a positive and significant influence on the operational performance of the manufacturing companies in Makassar Industrial Estate. This study supports the findings of previous scholars that JIT practices significantly improve operational performance and further competitive advantage can significantly improve operational performance, so it can be concluded that companies that have high performance will be able to achieve competitive advantage (Hadioetomo, 2009).

The results of this study refute the findings of previous researchers that most SMEs in the manufacturing sector do not apply JIT inventory management principles. This further revealed that there were challenges that hampered the application of the JIT principle in the 
manufacturing sector SMEs. These challenges include the lack of a trusted supplier network, lack of capital and lack of knowledge about direct financial benefits from the implementation of JIT (Mazanai, 2012; Moori et al., 2013).

\section{CONCLUSIONS}

Just-in-time consisting of Number of suppliers, Minimum inventory level, Improvement of factory layout, Reduction of setup time, Integrated quality control, Employee flexibility and significant positive effect on competitive advantage and operational performance in Manufacturing Companies in Industrial Estates Makassar. Competitive Advantage consisting of price determination, product quality, consistency of delivery, product innovation has a positive and significant influence on the operational performance of manufacturing companies in Makassar Industrial Estate. The hypothesis testing shows that there is a positive relationship between just in time and operational performance through competitive advantage. Competitive advantage can mediate positively and significantly on the influence of JIT on operational performance. But if just in time is directly related to operational performance, the results will still have a significant effect as mentioned in the fourth hypothesis. This means that JIT which is better and indirectly can improve operational performance through competitive advantage.

This study provides recommendations to the management of manufacturing companies should improve the customer relationship and share information so that operational performance can be increased in a high direction, but this is inseparable from good just in time management and also cannot be separated from the competitiveness of the company. Finally, for advanced researchers it is expected to develop the results of this study by adding several constructs (variables) or objects of research that have differences in the characteristics of the company. Conduct additional data collection techniques such as interviews with companies with the aim of increasing the number of respondents.

\section{References}

Alshbiel, SO, \& Al-Awaqleh, QA (2012). JIT production system and its effect on achieving industrial shareholding companies in Jordan. Interdisciplinary Journal of Contemporary Research In Business October, 4 (6).

Ansari, A., \& Modarress, B. (1988). JIT purchasing as a quality and productivity center. The International Journal of Production Research, 26 (1), 19-26. https://www.tandfonline.com/doi/abs/10.1080/00207548808947838

Brah, SA, \& Ying Lim, H. (2006). The effects of technology and TQM on the performance of logistics companies. International Journal of Physical Distribution \& Logistics Management, 36 (3), 192-209. https://doi.org/10.1108/09600030610661796

Carton, RB (2004). Measuring organizational performance: An exploratory study (Doctoral dissertation, University of Georgia).

Carton, RB, \& Hofer, CW (2006). Measuring organizational performance: Metrics for entrepreneurship and strategic management research. Edward Elgar Publishing.

Chen, YS, James Lin, MJ, \& Chang, CH (2006). The influence of intellectual capital on new product development performance-the manufacturing companies of Taiwan as an example. Total Quality Management and Business Excellence, 17 (10), 1323-1339. https://doi.org/10.1080/14783360601058979

Chi, T., Kilduff, PP, \& Gargeya, VB (2009). Alignment between business environment characteristics, competitive priorities, supply chain structures, and firm business performance. International Journal of productivity and performance management, 58 (7), 645-669. https://doi.org/10.1108/17410400910989467

Chin Lin, Y., \& Heng Tsai, P. (2009). The impact of a global logistics integration system on localization service and business competitive advantage. European Business Review, 21 (5), 418-437.

https://doi.org/10.1108/09555340910986655 
Christiansen, T., Berry, WL, Bruun, P., \& Ward, P. (2003). A mapping of competitive priorities, manufacturing practices, and operational performance in groups of Danish manufacturing companies. International Journal of Operations \& Production Management, 23 (10), 1163-1183. https://doi.org/10.1108/01443570310496616

Chyr, F., Lin, TM, \& Ho, CF (1990). Comparison between just-in-time and EOQ systems. Engineering Costs and Production Economics, 18 (3), 233-240. https://doi.org/10.1016/0167-188X(90)90125-2

Claycomb, C., Dröge, C., \& Germain, R. (1999). The effect of just-in-time with customers on organizational design and performance. The International Journal of Logistics Management, 10 (1), 37-58. https://doi.org/10.1108/09574099910805923

Cua, KO, McKone, KE, \& Schroeder, RG (2001). Between implementation relationships of TQM, JIT, and TPM and manufacturing performance. Journal of operations management, 19 (6), 675-694.

https://doi.org/10.1016/S0272-6963(01)00066-3

Danese, P., Romano, P., \& Bortolotti, T. (2012). JIT production, JIT supply and performance: investigating the moderating effects. Industrial Management \& Data Systems, 112 (3), 441-465.

https://doi.org/10.1108/02635571211210068

De Toni, A., \& Nassimbeni, G. (2000). Just-in-time purchasing: an empirical study of operational practices, supplier development and performance. Omega, 28 (6), 631-651. https://doi.org/10.1016/S0305-0483(00)00016-5

F. Hair Jr, J., Sarstedt, M., Hopkins, L., \& G. Kuppelwieser, V. (2014). Partial least squares structural equation modeling (PLS-SEM) An emerging tool in business research. European Business Review, 26 (2), 106-121. https://doi.org/10.1108/EBR-10-2013-0128

Fawcett, SE, \& Birou, LM (1993). Just-in-time sourcing techniques: Current state of adoption. Production and Inventory Management Journal, 34 (1), 18.

Fazel, F. (1997). A comparative analysis of inventory costs of JIT and EOQ purchasing. International Journal of Physical Distribution \& Logistics Management, 27 (8), 496-504. https://doi.org/10.1108/09600039710182680

Fazel, F., Fischer, KP, \& Gilbert, EW (1998). JIT purchasing vs. EOQ with a price discount: An analytical comparison of inventory costs. International Journal of Production Economics, 54 (1), 101-109.

https://doi.org/10.1016/S0925-5273(97)00130-8

Flynn, BB, Sakakibara, S., \& Schroeder, RG (1995). Relationship between JIT and TQM: practices and performance. Academy of management Journal, 38 (5), 1325-1360. https://doi.org/10.5465/256860

Gaspersz, Vincent. (2005). Integrated Performance Management System Balanced Scorecard With Six Sigma For Business Organizations and Government. Jakarta: PT Gramedia Pustaka Utama

Gaspersz, Vincent. (2008). Lean Six Sigma. Jakarta: PT Gramedia Pustaka Utama

Germain, R., Dröge, C., \& Daugherty, PJ (1994). The effect of just-in-time selling on organizational structure: an empirical investigation. Journal of Marketing Research, 471-483. https://doi.org/10.2307/3151877

Ghozali, I. (2011). Structural Equation Modeling Alternative Methods with Partial Least Square PLS.

Golhar, DY, \& Stamm, CL (1991). The just-in-time philosophy: a literature review. The International Journal of Production Research, 29 (4), 657-676. https://doi.org/10.1080/00207549108930094

González-Benito, J., \& Spring, M. (2000). JIT purchasing in Spanish auto components industry-implementation patterns and perceived benefits. International Journal of Operations \& Production Management, 20 (9), 1038 1061. https://doi.org/10.1108/01443570010339145

Hadioetomo, H. (2009). Effect of JIT Implementation on Performance and Competitive Advantages of Manufacturing Companies. ACCOUNTING STUDY, 4 (2), 104-113.

Hayes, RH, \& Schmenner, RW (1978). How should you organize manufacturing. Harvard Business Review, 56 (1), 105-118.

Heizer, J. \& Render, B. (2005). Flexible Version: Operation Management, 7th edition, New Jersey: Prentice Hall.

Inman, RA, Sale, RS, Green Jr, KW, \& Whitten, D. (2011). Agile manufacturing: relation to JIT, operational performance and firm performance. Journal of Operations Management, 29 (4), 343-355.

https://doi.org/10.1016/i.jom.2010.06.001

Kannan, VR, \& Tan, KC (2005). Just in time, total quality management, and supply chain management: understanding their linkages and impact on business performance. Omega, 33 (2), 153-162.

https://doi.org/10.1016/j.omega.2004.03.012 
Kotler, Philip \& Armstrong Gerry. (2003). Service Marketing Management. Salemba Empat: Jakarta

Lakhal, L., Pasin, F., \& Limam, M. (2006). Quality management practices and their impact on performance. International Journal of Quality \& Reliability Management, 23 (6), 625-646.

https://doi.org/10.1108/02656710610672461

Leavy, B. (1994). Two strategic perspectives on the buyer-supplier relationship. Production and Inventory Management Journal, 35 (2), 47.

Lee, SM, \& Ansari, A. (1985). Comparative analysis of Japanese just-in-time purchasing and traditional US purchasing systems. International Journal of Operations \& Production Management, 5 (4), 5-14.

https://doi.org/10.1108/eb054744

Li, S., Ragu-Nathan, B., Ragu-Nathan, TS, \& Rao, SS (2006). The impact of supply chain management practices on competitive advantage and organizational performance. Omega, 34 (2), 107-124.

https://doi.org/10.1016/i.omega.2004.08.002

Mazanai, M. (2012). Just-in-time impact (JIT) inventory system on efficiency, quality and flexibility among manufacturing sectors, small and medium enterprises (SMEs) in South Africa. African Journal of Business Management, 6 (17), 5786-5791. https://doi.org/10.5897/AJBM12.148

Meylianti, B. \& Mulia, F. (2009). Effect of JIT (Just In Time) and TQM (Total Quality Management) Implementation on Delivery Performance in the Automotive Industry in Indonesia. Journal of Applied and Theory Management | Journal of Theory and Applied Management, 2 (2).

Moori, RG, Pescarmona, A., \& Kimura, H. (2013). Lean manufacturing and business performance in Brazilian firms. Journal of Operations and Supply Chain Management, 6 (1), 91-105.

O'Neal, CR (1987). The buyer-seller linkage in a just-in-time environment. Journal of Purchasing and Materials Management, 23 (1), 7-13. https://doi.org/10.1111/i.1745-493X.1987.tb00174.x

Porter, ME (1990). New global strategies for competitive advantage. Planning Review, 18 (3), 4-14. https://doi.org/10.1108/eb054287

Ramarapu, NK, Mehra, S., \& Frolick, MN (1995). A comparative analysis and review of JIT "implementation" research. International Journal of Operations \& production management, 15 (1), 38-49. https://doi.org/10.1108/01443579510077188

Sakakibara, S., Flynn, BB, Schroeder, RG, \& Morris, WT (1997). The impact of just-in-time manufacturing and its infrastructure on manufacturing performance. Management Science, 43 (9), 1246-1257.

https://doi.org/10.1287/mnsc.43.9.1246

Schonberger, RJ, \& Gilbert, JP (1983). Just-in-time purchasing: a challenge for US industry. California Management Review, 26 (1), 54-68. https://doi.org/10.2307/41165050

Simamora, Bilson. (2002). Guide to Consumer Behavior Research. Jakarta: PT Gramedia Pustaka Utama

Sjahruddin, H., \& Sudiro, A. A. (2013). Organizational justice, organizational commitment and trust in manager as predictor of organizational citizenship behavior. Interdiciplinary J. of contemporary Res. Bus.(IJCRB), 4(12), 133141.

Slack, N., Lewis, M., \& Bates, H. (2004). The two worlds of operations management research and practice: can they meet, should they meet? International Journal of Operations \& Production Management, 24 (4), 372-387.

Staughton, R., \& Johnston, R. (2005). Operational performance gaps in business relationships. International Journal of Operations \& Production Management, 25 (4), 320-332.

https://doi.org/10.1108/01443570510585525

Stevenson, J William. (2002). Operation Management. NewYork: McGraw Hill

Tracey, M., \& Vonderembse, MA (2000). Building supply chains: a key to enhancing manufacturing performance. American Journal of Business, 15 (2), 11-20. https://doi.org/10.1108/19355181200000007

Venkatraman, N., \& Ramanujam, V. (1986). Measurement of business performance in research strategies: A comparison of approaches. Academy of Management Review, 11 (4), 801-814.

https://doi.org/10.5465/amr.1986.4283976

Voss, CA, Åhlström, P., \& Blackmon, K. (1997). Benchmarking and operational performance: some empirical results. International Journal of Operations \& Production Management, 17 (10), 1046-1058.

https://doi.org/10.1108/01443579710177059 
Waters-Fuller, N. (1995). Just-in-time purchasing and supply: a review of the literature. International journal of operations \& production management, 15 (9), 220-236. https://doi.org/10.1108/01443579510099751

Wook Kim, S. (2006). The supply chain integration effect on the alignment between corporate competitive capability and supply chain operational capability. International Journal of Operations \& Production Management, 26 (10), 1084-1107. https://doi.org/10.1108/01443570610691085 